\title{
Science Outreach and Science Education in the Primary Level: Conceptual and Pedagogical Challenges Faced
}

\author{
Diogo Gomes, Veronica McCauley \\ NUI Galway, Ireland
}

\begin{abstract}
To achieve economic growth, countries such as Ireland need to continue investing in scientific enterprise, which necessitates having more students choose and follow scientific careers. Current literature and policies point out that science education needs structural and methodological changes to respond to this objective of challenging our youth to choose science. This has resulted in an increasing call for science outreach interventions. The main objective of this study is to confront primary level teachers and science outreach practitioners with methodological issues for fostering students' interest in science. This mixed dialectic research method will be applied in order to investigate and design an effective model(s) of science outreach. It also aims to comprehend where the issues and tensions lie between science outreach and science education and how they affect the potential for the creation of partnerships between schools and outreach providers.
\end{abstract}

\section{Introduction}

Worldwide, science has become economically very important. The idea of a scientific society that needs an increasing number of science graduates in the workforce is dominant [1] The European Union and different EU countries, such as Ireland, stress that science and technology graduates are fundamental for economic growth [2], [3]. Nevertheless, reports show that, in Ireland the number of graduates in science, technology and mathematics' is not achieving the desired targets [4]. Ireland is not an isolated case, and a trend of diminishing interest in science has been identified in other countries [5], [6]. Therefore, policy documents of several countries state the need to change the way science is taught in schools and for further action to be taken to encourage students to pursue science degrees [4], [6]. Recent reports highlight the potential that informal science programs designed predominantly by Universities and other organizations, e.g. industry, for primary and second level students (henceforth denominated as science outreach programs) can have in improving student engagement in science and also as a direct vehicle in assisting science education in the classroom [7] For that, it is deemed that a stronger partnership between schools and science outreach providers is needed [4], [7]. The value of the partnership between schools and science outreach providers cannot be overemphasized, and as such forms the basis of this research. The main objective of this study is to compare the objectives and methodologies of science outreach practitioners and science education in the primary level classroom. As such, this study aims to make an informed contribution to the pedagogical objectives of science outreach and of the methodologies which should be used for attaining these.

\section{Literature review}

Changing science education, to make it more engaging and meaningful for students, is not a new aspiration. Schwab [8] was one of the first researchers to design a model for science education that favored inquiry based learning as opposed to a transmissive model of teaching. Since then, inquiry based learning has been exhaustively researched and different models have been developed [9]. The theoretical basis for inquiry based learning comes from theories of constructivist learning [10]. Although constructivist learning theory is often differentiated in terms of cognitive constructivism and social constructivism both contribute to inquiry based learning [11]. Therefore, the 
constructivist theory of learning, discussed in this paper, uses a synthesis of cognitive and social constructivist perspectives claiming that knowledge is personally constructed and socially mediated by the learner [12]. In short, changing science education towards constructivist rooted methodologies has a strong tradition in the science education literature [10].

In recent years, the number of students choosing science at university level has decreased [5]. As a result, there has been a renewed call for change in science education, and a move towards inquiry learning methods [4], [6]. The European Commission report [2] acknowledges that the focus of European level initiatives should be directed towards changing science teaching from deductive to inquiry based learning methods, in which the student has an active role in the learning process. Accordingly, science curricula and standards in several countries [13], [14] including Ireland [15] emphasize inquiry based learning methods. Nevertheless, this method has yet to become popular in terms of teaching practices in Ireland, where teachers continue to rely on the transmissive method of teaching [16]. The lack of support for science teaching is even more pressing at primary level. The majority of primary level teachers in Ireland do not have a background in science [17]. Furthermore, the science curriculum at primary level is less than ten years in existence, with a large number of the practicing teachers not having completed professional development in science education [18]. The difficulty in long term change towards inquiry based learning is not an isolated Irish problem and it is well reported in the literature [7], [19], as are primary teacher's challenges and issues in implementing meaningful inquiry learning [20].

The appeal for change in science education combined with the decreasing numbers of students choosing science related subjects at university level have impacted universities and science related organizations. Universities are now aware that they need to do more to attract students to science [7]. Therefore, the number of science outreach programs for primary and second level students is increasing, with a great number of them focusing on hands-on inquiry based learning activities [21], [22]. These science outreach programs, specifically directed at primary and second level students, have the potential to integrate more inquiry based learning in the science classroom and ideally impact an increased interest in science [2], [7]. The European Commission Report [2] advocates that science outreach can serve as a catalyst to accelerate the pace of change in science education. Stocklmayer et al. [7] argue that science outreach can create a third space in science education. Building on the work of Moje et al. [23] the third space is defined as one in which the formal school science (first space) and these informal programs (second space) merge; a programme that deliberately connects the curriculum content with the reality of science, a collaborative design that meets the needs of both parties (educator and outreacher), who both desire to enhance students' science education. The essence of the third space argument is in light of the fact that the increasing number of science outreach programs are often more than a once off or occasional experience that happens in the classroom; they can be a reality integrated in the everyday working of the formal sector of science education, increasing students' interest and comprehension of science.

In spite of the positive effects argued for science outreach in the enhancement of students' science education, a variety of issues have been identified. A recurrent one is the fact that researchers and outreach officers that develop these science outreach programs are often not aware of what happens in a classroom or of curriculum content/sequence. Therefore, science outreach practitioners see themselves as not having the skills or professional development to deal with the students [7], [24]. Consequently, it is argued that in order to contribute adequately to the creation of a third space, science outreach providers need to further develop connections with the curricula and schools. A second issue reported in the literature is that science outreach programs are still sporadic and incoherent depending on enthusiastic science outreach officers or volunteer scientists [6], [7]. Therefore, there is not often a structured approach to science outreach with clear methods and practical aims. This study examines these two issues, focusing on challenges faced by science outreach practitioners and primary level teachers when developing science activities.

\section{Research rationale}

Although there are concerns regarding student engagement and teaching methods, at both primary and secondary level, the author chose to 
focus on primary level for three reasons. Firstly, the literature shows that by the end of primary level education, most pupils have already ruled out science as a future career choice [25]. This is, therefore, considered a core time to motivate students for science [2]. The second reason has to do with teacher training/professional development in science education, or lack of, creating a valued opportunity for science outreach to intervene. And finally, there is already a great number of science outreach programs designed specifically to target primary level students in Ireland [26], and therefore suggested changes from this research could result in a substantial impact. Thus, the research participants in this research will be Irish primary level science teachers and science outreach practitioners.

The research questions that will be investigated are as follows:

- What conceptual and pedagogical challenges do teachers and science outreach practitioners face in the primary level classroom when developing an inquiry learning, hands-on curricular approach?

- What are the different solutions primary level teachers and science outreach practitioners offer to address the identified challenges?

- What is the reasoning and belief system behind the various solutions presented?

\subsection{Ecological view of Challenges faced by teachers}

This research aims to analyze teachers and science outreach practitioners' solutions and reflective thinking in response to challenges they face in the primary level science classroom. The challenges faced by teachers when trying to implement constructivist methodologies in education is not unique to science teachers. Windschitl [11] explains these challenges through a dilemmatic framework. The author defined four different levels of challenges faced by teachers: conceptual, pedagogical, cultural and political (table 1)

The methodological focus of this research builds upon Windschitl conceptualizations, particularly on the pedagogical and conceptual categories. The reasons for the selection of these categories and the exclusion of the cultural and political ones are now presented.

Science outreach practitioners usually develop their work within a school for a limited amount of time [27]. They are not present, and possibly cannot be expected to be, in a particular school every week or even every month. Therefore, their role in the cultural issues is an indirect one. Science outreach practitioners do not normally have a direct active role in the issues that arise in the school community whilst it reorganizes itself towards a constructivist science education, i.e. cultural dilemmatic types.

Table 1. Dilemma categories of constructivism in practice [11]

\begin{tabular}{|l|l|}
\hline Category & Dilemma rationale \\
\hline $\begin{array}{l}\text { Conceptu } \\
\text { al }\end{array}$ & $\begin{array}{l}\text { Grasping the underpinnings of cognitive and } \\
\text { social constructivism; reconciling learning } \\
\text { environment; reconciling current beliefs about } \\
\text { pedagogy with the epistemological orientations } \\
\text { necessary to support a constructivist learning. }\end{array}$ \\
\hline $\begin{array}{l}\text { Pedagogi } \\
\text { cal }\end{array}$ & $\begin{array}{l}\text { Honoring students attempts to think for } \\
\text { themselves while remaining faithful to accepted } \\
\text { disciplinary ideas; developing deeper } \\
\text { knowledge of subject matter; mastering the art } \\
\text { of facilitation; managing new kinds of } \\
\text { discourse and collaborative work in the } \\
\text { classroom. }\end{array}$ \\
\hline Cultural & $\begin{array}{l}\text { Becoming conscious of the culture of one's own } \\
\text { classroom; questioning assumptions about } \\
\text { what kinds of activities should be valued; } \\
\text { taking advantage of experiences, discourse } \\
\text { patterns, and local knowledge of students with } \\
\text { varied cultural backgrounds; managing the } \\
\text { collective transformation of students' beliefs } \\
\text { and practices in accordance with constructivist } \\
\text { norms. }\end{array}$ \\
\hline Political \\
$\begin{array}{l}\text { Confronting issues of accountability with } \\
\text { various stakeholders in the schoolroom } \\
\text { community; negotiating with key others the } \\
\text { authority and support to teach for } \\
\text { understanding. }\end{array}$ \\
\hline
\end{tabular}

The reasoning made for the cultural category also explains why political issues are out of the direct scope of science outreach practitioners. One of the argued advantages of the informal science outreach experiences is that they do not suffer from the type of pressures that science education does [7]. The objective of minimum competency in tests that push teachers to direct methods of instruction is one example of a pressure of this type [11]. These types of pressures do not directly influence the informal activities of science outreach. Therefore, as argued, outreach does not have a direct role in the cultural and political categories, albeit the relevant indirect influences. The indirect influences exist because these categories should be viewed in an ecological way [11]. The ecological view acknowledges that the four dilemmatic types are interconnected and therefore, although outreach work is more 
directly related to pedagogical and conceptual dilemmatic situations, the work developed by practitioners will obviously influence the cultural and political issues lived in school.

Following the rationalization as to why cultural and political categories are not directly relevant to outreach, it is necessary to understand why the other two (conceptual and pedagogical) are relevant to both teachers and science outreach practitioners. The reasoning for this argument comes directly from the specific work developed by science outreach practitioners. Science outreach origins and practices direct us to constructivism: hands on experiences for active engagement; inquiry learning experiences and the use of artifacts for open construction [21], [22]. Therefore, conceptual dilemmas, dilemmas that deal with grasping the concepts that guide constructivism, are directly relevant to science outreach practitioners. The same line of reasoning explains why pedagogical dilemmas are relevant to science outreach work. Pedagogical dilemmas are the ones which teachers face when designing the curriculum and learning experiences that constructivism demands. Curricular design is usually beyond the scope of a science outreach initiative [21], [22], however, designing learning experiences that foster constructivist objectives are the bread and butter of science outreach practitioners. A review of the literature reveals numerous examples of science outreach activities that enter the classroom with clear constructivist objectives connected with inquiry based learning activities [21]. Accordingly, these types of dilemmas are relevant to both teachers and outreach practitioners.

\subsection{Specific methodology used}

This study focuses on the conceptual and pedagogical categories of challenges, as previously explained. These categories are operationalized in dialectic dichotomies representing concepts (table 2) and pedagogical choices (table 3) that teachers and outreach practitioners face in their practice. The research participants will be presented with dilemmatic teaching/learning situations. Through a semistructured interview process they will reflect on the advantages and disadvantages of the choice of each term of the dichotomies. As in this research the use of dilemmas has the core objective of disclosing practitioners' reasoning, interviewing comes as the research method that can better reveal their thinking [28]. The methodology used in this research builds upon other studies that focus on having teachers illustrate and explain dilemmas they face in practice [28]; or on the analysis of selected dilemmas throughout a methods course [29]. In the case of this research, the methodology involves the design and presentation of contextualized and specific dilemmatic cases to both teachers and outreach practitioners. Each case will follow the classic definition of dilemma, in which two conclusive, opposing arguments will be presented. The use of dilemmas in such a way, and the method of confronting practitioners with them, stems from the dialectical approach followed. This research aims to unravel the tensions and contradictions faced by practitioners, when having to make choices during their practice in science education and outreach. The presented dialectical view is one which acknowledges that new knowledge is a constructed synthesis which resolves the inevitable contradictions arising during the course of interactions between individuals and their surrounding environment [30]. The dialectical use of dilemmas has the potential of producing contextualized reflection [28] as it can lead the research participants to interrogate their own beliefs and question institutional routines [11]. Consequently, it will be possible to gain a deeper understanding of teachers and outreach practitioners decisions and choices. For that, it is needed to ground and contextualize the concepts and situations that will be presented to the research participants

3.2.1 Conceptual dichotomies. The conceptual dichotomies (figure 1) are grounded in dialectical opposing concepts related with constructivist learning. The method used for the conceptual dichotomies involves research participants analyzing opposing views of each concept. Specifically, quotes from different authors, arguing in favor of each of the opposing concepts, are presented to the research participants. This method is consistent with previous studies, that used claims from researchers to evaluate research participants' beliefs regarding inquiry based learning [31]. 
Conceptual dichotomies

Autonomy

Figure 1. Conceptual dichotomies presented in the study

The first conceptual dichotomy presented is autonomy/dependency. One of the main concepts that guide a constructivist view of teaching is epistemological autonomy. As previously stated, this does not mean allowing the student to learn what she/he wants, when she/he desires, but an epistemological aim for the school to increment students' free thinking and construction of significations increasingly adapted to hers/his reality. As asserted by Windschitl [11], constructivism champions intellectual autonomy. The model favored by the Irish curriculum, inquiry learning, also champions the autonomy of the student. The inquiry learning model emphasizes the progressive path the student undertakes to achieve an autonomous inquiry capacity. Progressive is a key word here, as autonomy is a constructed path. As stated by Blanchard [19] a fundamental misunderstanding of the model of inquiry based learning is assuming that this method gives total autonomy to the student without any scaffolding by the teacher. The dialectical opposite of autonomy is dependency, where the teacher controls every aspect of the learning process. It is represented by an objectivist type of teaching [16], in which lecturing and demonstration are the favored modes of teaching. This model stems from the belief that language can be used as a precise tool to describe reality and transfer it to students. These two epistemological oppositions or dichotomies will allow the research participant to reflect between the two opposite concepts and select hers/his personal position along the continuum that exists between the two [32].

The second dichotomy that will be presented to the research participants is induction/deduction. This specific dichotomy is one which is discussed extensively in the science education literature. It is usually set in the terms of what to teach: the product of science through a deductive methodology or the processes of science through an inductive methodology, in which the student through the process reaches the product [7]. Although the latter is normally the one associated with a constructivist methodology [33], this is erroneous [11]. Both inductive and deductive thinking are present in the construction of knowledge. The statements selected for this dichotomy are statements that represent the extremes of this dialectical continuum. Inductive thinking emphasizes the construction of the concept by the student through a process of interiorisation, in which the teacher facilitates carefully selected objects, examples and information. On the other hand deductive methodology believes that the wider concept should be presented first and then teachers should go to more specific and concrete particularities that will allow the better understanding of the initial concept presented.

The third dichotomy presented is creativity/guidance. A constructivist view of teaching is one that automatically demands creative thinking [34]. As was previously discussed, a constructivist philosophy of learning stresses the role of knowledge creation in opposition to transmission of knowledge. This automatically directs us to creativity. The creation and implementation of ideas is one of the main objects of studies on creativity [35]. Givens [36] gives us a working definition of what it means to be creative in the science classroom. The author states that children are creative when constructing meaning, explanations, hypothesis and procedures that are new to them. One can acknowledge now that the curricular models which emphasize inquiry learning should be able to promote creative thinking. Nevertheless, the fact is that the literature reports that inquiry learning per se does not guarantee a fostering of creativity [35]. The reasons put forward for this are usually of a pragmatic nature. Teachers, due to several constraints (e.g. curriculum, time, exams) need to frame inquiry learning in specific pre-determined activities (investigations) and do not leave space for students to embark in their own divergent thinking. As Ronald ([37], p.45) argued: "the habitual dismissal of unique ideas spells trouble for the cultivation of creative thinking". The reasons stated for the lack of fostering of creative thinking in the classroom leads us to the dialectical opposite of creativity, guidance. The constraints teachers face leads them to a method of teaching where students are restricted in terms 
of their creativity and guided towards the right answers that schooling values. The statements presented to the research participants will be ones that argue for each of these dialectical poles in the literature, creativity and guidance. These three conceptual dichotomies (autonomy/dependency, creativity/guidance and deduction/induction) are selected in this research to analyze and compare research participants' positions regarding core constructivist conceptualizations.

3.2.2 Pedagogical dichotomies. Although conceptual dichotomies are core to the understanding of epistemological positions, pedagogical dilemmas are equally as relevant. Pedagogical dilemmas are the ones that deal with the concrete, with the contextualized activities teachers and outreach practitioners develop with the students. Therefore, the pedagogical choices made in these dichotomies may or may not align with conceptual positions taken. This is what has been called the dichotomy beliefs/practice in which teachers' beliefs are often not reflected in their practice [38].

The pedagogical dichotomies are designed from specific activities selected by the Irish curriculum. The research participants will examine, through a semi-structured interview, curricular activities designed according to the opposing dialectical concepts (figure 2).

The use of the curriculum to generate instruments to be presented to teachers has strong support in the science education literature [35]. It is argued that notions of learning relate to practice more closely when they are assessed at such a specific level. Adding to this, the Irish primary science curriculum offers various possibilities, in terms of practices, for the teachers. The curriculum can be recreated following different reasonings and beliefs [39]. The topics and activities suggested by the curriculum can be presented according to different conceptualizations of science education. The curriculum can then be followed according to either of the dialectical poles of the conceptual dilemmas, or somewhere in the continuum between them. This autonomy of the teacher, which the Irish curriculum allows, is not unique to this curriculum. It represents a trend visible in different countries. This trend follows the reasoning that it is the role of the teacher, according with the specific context that she/he deals with, to select the methodologies that best serve hers/his students[15]. This autonomy reinforces the use of the dialectical dilemmas, as these are choices that teachers make in practice. The Irish Government, through the Discover Primary Science program (DPS), strongly supports teachers in terms of resources and methodologies, specifically designed for teaching the Irish primary science curriculum [40]. DPS activity sheets and guidelines for teachers are designed to support their teaching of the strands (curricular content) and skills. In order to contextualize the pedagogical dilemmas further, the dilemmas are based in the specific strands and skills of the Irish Curriculum and with specific activities that DPS developed for teachers to use.

\begin{tabular}{|lr|}
\hline \multicolumn{2}{|l|}{ Pedagogical dichotomies } \\
\hline $\begin{array}{l}\text { Open } \\
\text { inquiry }\end{array}$ \\
$\begin{array}{l}\text { Activity selected to be presented } \\
\text { dialectical poles: }\end{array}$ \\
- Thquiry \\
investigate factors that affect plant growth )
\end{tabular}

Figure 2. Pedagogical dichotomies used in the study

The first pedagogical dichotomy presented is open vs structured inquiry. One of the two groups of skills that the Irish primary science curriculum aims to develop in the classroom is working scientifically. Henceforth, investigating/ experimenting through inquiry learning, is at the core of the development of this group of skills. Nevertheless, inquiry learning can itself be dialectical. As stated by Abrams et al. [41], inquiry learning can go from a level zero inquiry, 
completed directed and controlled by the teacher; to a level three inquiry, completely open to the student. It is, then, the choice of the practitioner which type of inquiry learning model she/he develops with their students.

The open experimentation assumes the student is given total autonomy, in which the teacher's role is as a facilitator or coach who engages and encourages students to be responsible for their own learning and to question, explore from their own explanations, and make decisions. With such a model, students have a significant voice in decisions about what activities to do, which is believed to increase the student's interest and motivation [42]. The guided experimentation brings more dependency, with the teacher assuming the control of the experiment, ensuring that the student is gaining at least a superficial understanding of all scientific aspects of a project [42].

The second pedagogical dichotomy presented is open vs specific construction. In line with this, another group of skills that the Irish Curriculum aims to develop is designing and making. This group of skills is designed to "encourage the creative and imaginative aspects of the science process" ([15]. P. 47). It is evident from this quote that creativity is a big part of what this group of skills is about. One of the key components to develop creativity is uniqueness [37]. It is argued that although uniqueness must be balanced with relevance, if too much emphasis is put on relevance, the opportunity to enhance creativity is lost. Henceforth, open vs specific construction is the dialectic opposition that will be put in this dilemma. Construction of objects is an important skill developed throughout the curricular strands. This construction can be left open for the student, with the student deciding what to build, thus increasing his/her creative freedom, i.e., uniqueness. On the other hand the construction can be specific, with the teacher controlling what is being made, i.e., increasing its relevance.

The last dichotomy presented will be observation and identification vs experimentation. The skill group working scientifically is divided in several different skills that go from pure deduction to pure induction. It is then the choice of the teacher to decide what type of skill she/he aims to develop with the students within the various strands. They can follow a deductive method, by explaining the general concept first and then students applying them to concrete cases. Alternatively the students can comprehend the same concept through an inductive path; by experiencing a concrete case the student induces the concept. This pedagogical dilemma is directly related to the conceptual dilemma induction/deduction, revealing two distinctly different epistemological positions. It is this dialectical opposition that will be presented to the research participants.

\section{Analysis of findings}

As this is still a work in progress, at this moment there are still no findings to be presented and/or analyzed. Nevertheless, it can be advanced that the analysis will follow a mixed methods nature, in which qualitative and quantitative methods of analysis will be employed, congruent with the rationale of the study and of previous research work that followed an equivalent methodology [43].

\section{Conclusions}

As science outreach is becoming a relevant and valued presence in primary schools [2], this study aims to further enhance these practices through the analysis of these dilemmatic cases from the perspective of both teachers and outreach practitioners. Three main reasons justify this. First, science outreach practitioners can offer valuable new views on dilemmas in science education [24]. Second, by identifying and understanding these dilemmas, science outreach practitioners can incorporate new insights in the development of their programmes to promote science to youngsters [7]. Third, by comparing the objectives and methodologies of science outreach and science education for the primary level, this study may contribute towards enhancing pedagogical objectives of science outreach and the methodologies which should be used for attaining these aims. These insights can potentially assist in the effective creation of the aforementioned third space in the context of primary level science education and science outreach in Ireland, enabling the formation of a collaborative community of elementary science education.

\section{References}

[1] J. Osborne and J. Dillon, Good practice in science teaching: what research has to say. Berkshire, 
England: Buckinghamshire, England: Open University, 2010.

[2] E. European Commission, High Level Group on Science, "Science education now a renewed pedagogy for the future of Europe," 2007. [Online]. Available: http://ec.europa.eu/research/sciencesociety/document_library/pdf_06/report-rocard-onscience-education_en.pdf.

[3] E. and I. Ireland. Department for Jobs, "Strategy for Science, Technology and Innovation Indicators December 2011 ." Forfas, [Online], 2011. [4] C. Of, T. H. E. European, and European Commission, "Progress towards the Common European Objectives in Education and Training," 2011.

[5] G. S. F. OECD and G. S. Forum, "Evolution of student interest in science and technology studies: Policy report," 2006.

[6] O. J. Tytler and G. Williams, "Opening up pathways: Engagement in STEM across the PrimarySecondary school transition: review of the literature concerning supports and barriers to Science, Technology, Engineering and Mathematics engagement at Primary-Secondary transition. Commissioned." Dealin University, Melbourne, 2008. [7] S. M. Stocklmayer, L. J. Rennie, and J. K. Gilbert, "The roles of the formal and informal sectors in the provision of effective science education," Studies in Science Education, vol. 46, no. 1, pp. 1-44, 2010. [8] Schwab, "Biological Sciences Curriculum Study." New York, 1965.

[9] C. E. Hmelo-Silver, R. G. Duncan, and C. A. Chinn, "Scaffolding and Achievement in ProblemBased and Inquiry Learning: A Response to Kirschner, Sweller, and Clark (2006)," Educational Psychologist, vol. 42, no. 2, pp. 99-107, 2007. [10] M. R. Matthews, "Constructivism and science education: A further appraisal," Journal of Science Education and Technology, vol. 11, no. 2, pp. 121134 , 2002.

[11] M. Windschitl, "Framing constructivism in practice as the negotiation of dilemmas: An analysis of the conceptual, pedagogical, cultural, and political challenges facing teachers," Review of Educational Research, vol. 72, no. 2, pp. 131-175, Jan. 2002. [12] K. G. Tobin, The Practice of constructivism in science education. Hillsdale; Hove: Lawrence Erlbaum Associates, 1993.

[13] B. National Curriculum, "The shape of the Australian curriculum English, mathematics, science and history," 2009. [Online]. Available: http://www.ncb.org.au/verve/_resources/Shape_of_the Australian Curriculum.pdf.

[14] C. National Research, "Successful K-12 STEM Education: Identifying Effective Approaches in Science, Technology, Engineering, and Mathematics." The National Academies Press, Washington, 2011. [15] DES, "Primary School Curriculum - Science." Stationery Office, Dublin, 1999.
[16] G. Shiel, "OECD Teaching and Learning International Study (TALIS)."

[17] M. Killeavy, "Teacher Education in Ireland: The induction and continuing professional development of primary teachers," European Journal of Teacher Education, vol. 24, no. 2, pp. 115-132, 2001. [18] C. M. Janet Varley Órlaith Veale, B. J. Varley, C. Murphy, Ó. Veale, and S. Patrick, "Science in Primary Schools, Phase 1 Final Report," no. May, pp. 1-215, 2008.

[19] M. R. Blanchard, S. A. Southerland, J. W. Osborne, V. D. Sampson, L. A. Annetta, and E. M. Granger, "Is inquiry possible in light of accountability?: A quantitative comparison of the relative effectiveness of guided inquiry and verification laboratory instruction," Science Education, vol. 94, no. 4, pp. 577-616, 2010. [20] K. Appleton, Elementary science teacher education : international perspectives on contemporary issues and practice. Mahwah, N.J.; London: Lawrence Erlbaum Associates, 2006. [21] V. Crane and F. National Science, Informal science learning: what the research says about television, science museums, and community-based projects. Dedham, MA: Research Communications Ltd., 1994.

[22] A. T. Jeffers, A. G. Safferman, S. I. Safferman, and M. Asce, "Understanding K -12 Engineering Outreach Programs," no. April, pp. 95-109, 2004. [23] E. B. Moje, K. M. Ciechanowski, K. Kramer, L. Ellis, R. Carrillo, and T. Collazo, "Working toward third space in content area literacy: An examination of everyday funds of knowledge and Discourse," Reading Research Quarterly, vol. 39, no. 1, pp. 38-70, 2004. [24] H. Thiry, S. L. Laursen, and A. B. Hunter, "Professional development needs and outcomes for education-engaged scientists: A research-based framework," Journal of Geoscience Education, vol. 56, no. 3, pp. 235-246, 2008

[25] S. I. van Aalderen-Smeets, J. H. Walma van der Molen, and L. J. F. Asma, "Primary teachers' attitudes toward science: A new theoretical framework," Science Education, vol. 96, no. 1, pp. 158-182, Jan. 2012.

[26] K. Davison, "A review of Science Outreach Strategies North and South. Report for the Standing Conference on Teacher Education North and South ." 2008.

[27] A. T. Jeffers, A. G. Safferman, and S. I. Safferman, "Understanding K-12 engineering outreach programs," Journal of Professional Issues in Engineering Education and Practice, vol. 130, no. 2, pp. 95-108, 2004.

[28] H. H. Yoon and M. Kim, "Collaborative Reflection through Dilemma Cases of Science Practical Work during Practicum," International Journal of Science Education, vol. 32, no. 3, pp. 283301, Feb. 2010.

[29] D. Tippins, S. Nichols, and T. Dana, "Exploring novice and experienced elementary teachers' science 
teaching and learning referents through videocases," Research in Science Education, vol. 29, no. 3, pp. 331-352, 1999.

[30] M. David, "Exogenous, endogenous, and dialectical constructivism," Developmental Review, vol. 2, no. 4, pp. 371-384, 1982. [31] J. L. Bencze and G. M. Bowen, 'Student-teachers' dialectically developed motivation for promoting student-led science projects," no. November 2006, pp. 133-159, 2007.

[32] L. J. Moniz and L. Barros, Psicologia da doença para ciudados de saúde: desenvolvimento e intervenção [; guia metodológico dirigido a psicólogos, médicos, enfermeiros e outros técnicos de saúde. Lisboa: 2005. [33] P. A. Kirschner, J. Sweller, and R. E. Clark, "Why minimal guidance during instruction does not work: An analysis of the failure of constructivist, discovery, problem-based, experiential, and inquiry-based teaching," Educational Psychologist, vol. 41, no. 2, pp. 75-86, 2006.

[34] N. Boddy, K. Watson, P. Aubusson, S. Education, and K. A. Publishers, "A trial of the Five Es: A referent model for constructivist teaching and learning," Research in Science Education, vol. 33, no. 1, pp. 2742, 2003.

[35] L. D. Newton and D. P. Newton, "What Teachers See as Creative Incidents in Elementary Science Lessons," International Journal of Science Education, vol. 32, no. 15, pp. 1989-2005, Oct. 2009. [36] P. R. Givens, "Identifying and Encouraging Creative Processes: The Characteristics of the Creative Individual and the Environment That Fosters Them," The Journal of Higher Education, vol. 33, no. 6, pp. 295-301 CR - Copyright \&\#169; 1962 Ohio State Uni, Jun. 1962.

[37] B. Ronald A and R. a. Beghetto, "Does creativity have a place in classroom discussions? Prospective teachers' response preferences," Thinking Skills and Creativity, vol. 2, no. 1, pp. 1-9, Apr. 2007. [38] M. Ebbers and P. Rowell, "Shaping school science: competing discourses in an inquiry-based elementary program," International Journal of Science Education, vol. 26, no. 8, pp. 915-934, Jun. 2004. [39] R. Pintó and R. Pint, "Introducing curriculum innovations in science: Identifying teachers' transformations and the design of related teacher education," Science Education, vol. 89, no. 1, pp. 112, Jan. 2005.

[40] DPS, "Discover primary Science," Discover Primary Science \& Maths - Teachers resources, 2012. [Online]. http://www.primaryscience.ie/

teachers_introduction.php.

[41] E. Abrams, S. A. Southerland, and P. C. Silva, Inquiry in the classroom: realities and opportunities. Charlotte, $\quad$ N.C.: $\quad$ IAP, 2008. [42] K. S. Davis, "'Change is hard': What science teachers are telling us about reform and teacher learning of innovative practices," Science Education, vol. 87, no. 1, pp. 3-30, Jan. 2003.
[43] J. H. William S. Harwood Christine Lother, W. S. Harwood, J. Hansen, and C. Lotter, "Measuring Teacher Beliefs About Inquiry: The Development of a Blended Qualitative/Quantitative Instrument," Journal of Science Education and Technology, vol. 15, no. 1, pp. 69-79, Mar. 2006. 